\title{
PEMANFAATAN LIMBAH ABU TEMPURUNG KELAPA SAWIT UNTUK CAMPURAN MORTAR
}

\author{
Asri Mulyadi ${ }^{1)}$, Gyan Laksana ${ }^{2)}$ \\ Program Studi Teknik Sipil Fakultas Teknik Universitas Palembang \\ Jalan Dharmapala No.1A Bukit Besar Palembang 30139 \\ e-mail : asri_anang@yahoo.co.id ${ }^{1)}$,dumyatiahmad@yahoo.co.id ${ }^{2)}$
}

\begin{abstract}
ABSTRAK
Mortar adalah campuran yang terdiri dari material pasir, material semen dan air. Konsistensi mortar ini nantinya akan berguna dalam menentukan kekuatan mortar yang menjadi spesi, plesteran dinding, batako dan sebagainya, sehingga diharapkan mortar yang menahan gaya tekan akibat beban yang bekerja padanya tidak hancur, maka pada penelitian yang kami lakukan kali ini, kami mencoba menggunakan limbah abu tempurung kelapa sawit sebagai bahan tambahan pada campuran mortar sebesar $0 \%, 5 \%, 10 \%, 15 \%$ dari berat semen. Pada penelitian ini beda uji dicetak dengan menggunakan kubus baja ukuran $5 \mathrm{~cm}$ x $5 \mathrm{~cm} \times 5 \mathrm{~cm}$, masing-masing umur mortar yaitu 7 hari, 14 hari, 21 hari dan 28 hari dengan pengujian kuat tekan mortar. Komposisi campuran Mortar Standar (MS) dan Mortar yang dicampur dengan Limbah abu tempurung kelapa sawit (MA sebesar 0 gr, 12,5gr, $25 \mathrm{gr}, 37,5 \mathrm{gr}$, dan faktor air semen adalah 0,484 untuk semua jenis semen portland. Dari hasil evaluasi uji kuat tekan yaitu pada mortar tanpa menggunakan material tambahan Limbah abu tempurung kelapa sawit atau Mortar Standar (MS) pada umur Mortar 28 hari didapat kuat tekan Mortar sebesar 47,33 $\mathrm{kg} / \mathrm{cm}^{2}$, pada mortar yang menggunakan material tambahan Limbah abu tempurung kelapa sawit 5\% pada umur mortar 28 hari didapat kuat tekan mortar sebesar $43,87 \mathrm{~kg} / \mathrm{cm}^{2}$, pada mortar yang menggunakan material tambahan Limbah abu tempurung kelapa sawit 10\% pada umur mortar 28 hari didapat kuat tekan mortar sebesar $38,13 \mathrm{~kg} / \mathrm{cm}^{2}$ dan mortar yang menggunakan material tambahan Limbah abu tempurung kelapa sawit $15 \%$ pada umur mortar 28 hari didapat kuat tekan mortar sebesar $36,00 \mathrm{~kg} / \mathrm{cm}^{2}$.
\end{abstract}

Kata Kunci : Kuat Tekan Mortar, Agregat Halus, Limbah abu tempurung kelapa sawit.

\section{PENDAHULUAN}

\section{A. Latar Belakang}

Mortar adalah campuran yang terdiri dari material pasir, material semen dan air. Bahan perekat dapat berupa tanah liat, kapur dan semen. Apabila yang dipakai sebagai perekat adalah tanah liat, maka disebut mortar lumpur. Sedangkan untuk yang perekat yang menggunakan kapur disebut mortar kapur, dan bila dari semen portland disebut mortar semen [4], mortar mempunyai kuat tekan bervariasi sesuai dengan bahan penyusunya dan perbandingan antara bahan-bahan penyusunya [2]. Perbandingan semen, pasir dan air yang sesuai untuk mortar yang memiliki syarat adalah $1: 2,75: 0,484$. sebagai bahan pengikat, mortar harus mempunyai konsistensi /kekentalan standar. Konsistensi mortar ini nantinya akan berguna dalam menentukan kekuatan mortar yang menjadi spesi, plesteran dinding, batako dan sebagainya, sehingga diharapkan mortar yang menahan gaya tekan akibat beban yang bekerja padanya tidak hancur. Agregat halus merupakan pasir alam hasil desintegrasi alami dari batu atau pasir yang dihasilkan oleh industri pemecah batu dengan ukuran butir terbesar 5,0 mm[3], maka pada penelitian yang kami lakukan kali ini, kami mencoba menggunakan limbah abu tempurung kelapa sawit sebagai bahan tambahan pada campuran mortar sebesar $0 \%$, $5 \%, 10 \%, 15 \%$ dari berat semen.

\section{B. Tujuan Penelitian}

Tujuan yang ingin di capai dari penelitian ini adalah :

1. Mengetahui jumlah optimum limbah abu tempurung kelapa sawit terhadap kuat tekan mortar.

2. Untuk menentukan besarnya kuat tekan mortar dengan umur 28 hari yang 
menggunakan limbah abu tempurung kelapa sawit sebagai tambahan pada campuran mortar dengan contoh benda uji berbentuk kubus berukuran $5 \mathrm{~cm} \times$ $5 \mathrm{~cm} \times 5 \mathrm{~cm}$.

\section{Manfaat Penelitian}

Adapun manfaat yang diharapkan adalah sebagaiberikut :

1. Menghasilkan mortar yang mempunyai kuat tekan yang sama atau bahkan lebih tinggi dari mortar yang tidak menggunakan limbah abu tempurung kelapa sawit sebagai bahan tambahan.

2. Memberikan kontribusi baru dalam dunia konstruksi terutama dalam bidang finishing dinding bata supaya tahan terhadap air.

\section{Rumusan Masalah}

Rumusan masalah yang diambil dari penelitian ini adalah berapa besar kuat tekan optimum mortar dengan menggunakan limbah abu tempurung kelapa sawit sebagai bahan tambahan pada umur 28 hari.

\section{E. Batasan Masalah}

Batasan masalah didalam penelitian ini penulis membatasi ruang lingkup pekerjaan pengujian - pengujian bahan material dan benda uji kuat tekan mortar di laboratorium.

\section{TINJAUAN PUSTAKA}

\section{A. Mortar}

Mortar adalah adukan yang terdiri dari pasir, bahan perekat dan air. Bahan perekat dapat berupa tanah liat, kapur dan semen. Apabila yang dipakai sebagai perekat adalah tanah liat, maka disebut mortar lumpur. Sedangkan untuk yang perekat yang menggunakan kapur disebut mortar kapur, dan bila dari semen portland disebut mortar semen [4], yang memiliki persentase yang berbeda. Perbandingan pasir, semen dan air yang sesuai untuk mortar yang memenuhi syarat adalah $2,75: 1: 0,485$. Sebagai bahan pengikat, mortar harus mempunyai konsentrasi /kekentalan standar. Konsentrasi mortar ini nantinya akan berguna dalam menentukan kekuatan mortar yang menjadi spesi ataupun plesteran dinding sehingga diharapkan mortar yang menahan gaya tekan akibat beban yeng bekerja padanya tidak hancur (Teknologi Beton, 2008)

\section{B. Spesifikasi Mortar}

1. Spesifikasi proporsi dan Sifat Mortar Berdasarkan SNI 03-6882-2002, proporsi mortar di spesifikasikan dalam 4 tipe menurut kekuatan mortar dan ketentuan spesifikasi proporsi bahan yang terdiri dari semen, agregat halus, dan air. Sebagai berikut mortar tipe $\mathrm{M}$, mortar tipe $\mathrm{S}$, mortar tipe $\mathrm{N}$, dan mortar tipe $\mathrm{O}$.

2. Metode Pengujian

Proporsi campuran bahan untuk benda uji Mortar yang dibuat dilaboratorium yang digunakan untuk menentukan sifat - sifat menurut spesifikasi ini harus berisi bahan bahan konstruksi dalam susunan campuran yang telah ditetapkan dalam spesifikasi proyek (SNI 03-6882-2002).

3. Kuat Tekan Mortar

Untuk mengetahui perbandingan kuat tekan mortar dengan varian berbeda, perhitungan kuat tekan mortar menggunakan rumus :

$$
\begin{aligned}
F c & =\frac{P}{A} \\
\mathrm{Fc} & =\text { Kuat tekan benda uji }\left(\mathrm{kg} / \mathrm{cm}^{2}\right) \\
\mathrm{P} & =\text { Beban tekan maksimum }(\mathrm{kg}) \\
\mathrm{A} & =\text { Luas bidang tekan }\left(\mathrm{cm}^{2}\right)
\end{aligned}
$$

\section{Material Campuran Mortar}

1. Semen

Material semen adalah material yang mempunyai sifat-sifat adhesif dan kohesif yang diperlukan untuk mengikat agregatagregat menjadi suatu massa yang padat yang mempunyai kekuatan yang cukup.

2. Agregat Halus

Agregat halus merupakan pengisi yang berupa pasir. Agregat halus yang baik harus bebas bahan organik, lempung, partikel yang lebih kecil, atau bahan-bahan lain yang dapat merusak campuran. Variasi ukuran dalam suatu campuran barus mempunyai gradasi yang baik.

3. Air

Air diperlukan pada pembuatan mortar untuk memicu proses kimiawi semen, membasahi agregat dan memberi kemudahan dalam pekerjaan mortar. 


\section{METODOLOGI PENELITIAN}

\section{A. Umum}

Metodologi penelitian merupakan cara yang digunakan dalam penelitian, sehingga dalam pelaksanaan dan hasil penelitian dapat dipertanggung jawabkan secara ilmiah. Penelitian yang dilakukan adalah berada pada skala laboratorium dengan tahapan-tahapan yang sesuai dengan literatur sehingga didapatkan hasil yang baik dan dapat mencerminkan keadaan yang sebenarnya serta dapat dipertanggungjawabkan.

\section{B. Tahapan Persiapan}

Tahap persiapan yaitu menyiapkan bahan dan peralatan yang akan digunakan dalam penelitian pembuatan mortar dengan campuran limbah abu tempurung kelapa sawit.

Bahan dan peralatan yang akan digunakan adalah :

1. Bahan

Bahan yang digunakan dalam penelitian ini adalah :

- Semen

Dalam penelitian ini semen yang digunakan adalah semen Portland Tipe I merek Semen Baturaja.

- Agregat halus adalah pasir sungai musi.

- Air yang dipakai dalam penelitian ini adalah air PDAM yang terdapat di Lab. Program Studi Teknik Sipil Politeknik Negeri Sriwijaya

- Limbah abu tempurung kelapa sawit.

2. Peralatan

Alat yang digunakan dalam penelitian ini adalah sebagai berikut :

1. Timbangan dengan ketelitian 0,1 gram

2. Gelas ukur $1000 \mathrm{ml}$

3. Piknometer.

4. Kerucut terpancung

5. Batang perojok

6. Pan aluminium

7. Pelat kaca

8. Cawan

9. Oven yang dilengkapi pengatur suhu.

10.Density spoon

11. Timbangan

12.Tabung silinder

13.Jangka sorong

14.Kuas

15.Ember plastic

16.Cetakan kubus dengan ukuran $(5 \mathrm{x} 5 \mathrm{x}$ 5) $\mathrm{cm}$
17.Sendok semen

18. Mesin uji tekan A Macklon - Smith LTD serial No. T223/70

19. Ayakan, Lolos saringan No. 200 (komposisi agregat halus sesuai dengan standar)

20. Kain basah.

\section{Perencanaan Campuran}

Campuran mortar berpedoman pada Standard ASTM C109-93, yaitu:

- Cetakan kubus 50 x 50 x $50 \mathrm{~mm}$

- Sampel dapat dibuat dengan perincian bahan adalah:

\begin{tabular}{|l|c|}
\hline & 3 sampel \\
\hline Semen & 250 gram \\
\hline Pasir & 687,5 gram \\
\hline Air & $121 \mathrm{ml}$ \\
\hline
\end{tabular}

\section{Prosedur Pembuatan Bahan Uji Mortar}

1. Pencampuran

Bahan-bahan seperti semen dan pasir ditimbang dengan perbandingan $1: 2,75$ dan abu tempurung kelapa sawit sebanyak $0 \%, 5 \%, 10 \%$, dan $15 \%$ dari berat semen.

2. Pengadonan

Setelah semua bahan dicampur maka bahan tersebut diberi air pada bagian tengah adonan serta dibiarkan selama 60 detik agar campuran saling mengikat lalu campuran tersebut diaduk sampai campuran benarbenar homogen.

3. Pencetakan

Setelah pengadonan selesai dilakukan pencetakan dengan memasukkan pasta mortar kedalam cetakan kubus yang telah diolesi Vaseline

\section{E. Prosedur Pengujian Kuat Tekan Mortar}

Pengujian kuat tekanan mortar dilakukan untuk mengetahui kuat tekan hancur dari benda uji tersebut. Benda uji yng dipakai adalah kubus dengan ukuran sisinya $(5 \times 5 \times 5) \mathrm{cm}$. pengujian kuat tekanan mortar dilakukan saat mortar berumur 7, 14, 21 dan 28 hari. Jumlah mortar yang di uji yaitu terdiri dari 3 buah sampel untuk masing-masing campuran.

Prosedur kerja untuk pengujian kuat tekan pada benda uji mortar, antara lain : 
1. Dikeluarkan benda uji setelah mencapai umur yang direncanakan dari bak perendaman lalu dikeringkan dengan lap dan dibiarkan selama 24 jam.

2. Benda uji diletakkan pada mesin penekan.

3. Diberikan beban tekan secara perlahanlahan pada benda uji dengan cara mengoperasikan tuas pompa sehingga benda uji runtuh dan hancur.

4. Pada saat jarum penunjuk skala beban tidak lagi bergerak atau bertambah maka skala yang ditunjukkan oleh jarum tersebut dicatat sebagai beban maksimum yang dapat dipikul oleh benda uji tersebut.

5. Prosedur ini diulang untuk sampel benda uji kuat tekan yang lain.

Kuat tekan dapat diperoleh dengan rumus, sebagai berikut :

$$
F c=\frac{P}{A}
$$

Dengan :

$$
\begin{aligned}
& \mathrm{Fc}=\text { Kuat tekan benda uji }\left(\mathrm{kg} / \mathrm{cm}^{2}\right) \\
& \mathrm{P}=\text { Beban tekan maksimum }(\mathrm{kg})
\end{aligned}
$$$$
\mathrm{A}=\text { Luas bidang tekan }\left(\mathrm{cm}^{2}\right)
$$

\section{ANALISIS DAN PEMBAHASAN}

\section{A. Karakteristik Agregat}

Material yang digunakan dalam penelitian ini yaitu agregat halus (pasir) dari sungai musi. Pengujian agregat ini mengacu pada SNI (Standar Nasional Indonesia). Pengujian ini dilakukan di Lab. Struktur dan Bahan Program Studi Teknik Sipil Fakultas Teknik Universitas Palembang, dan Lab. Program Studi Teknik Sipil Politeknik Negeri Sriwijaya. Hasil pemeriksaan agregat halus

\begin{tabular}{|c|c|c|c|c|}
\hline \multirow[b]{2}{*}{ No. } & \multirow[b]{2}{*}{ Pengujian } & \multirow[b]{2}{*}{ Parameter } & \multirow[b]{2}{*}{ Syarat } & Hasil \\
\hline & & & & $\begin{array}{c}\text { Pasir } \\
\text { Palembang }\end{array}$ \\
\hline 1 & $\begin{array}{l}\text { Kadar } \\
\text { lumpur }\end{array}$ & & $\leq 5 \%$ & 1,27 \\
\hline 2 & $\begin{array}{l}\text { Berat jenis } \\
\text { dan } \\
\text { penyerapan } \\
\text { agregat }\end{array}$ & $\begin{array}{l}\text { Berat jenis } \\
\text { kering } \\
\text { permukaan }\end{array}$ & $2,5-2,7$ & 2,55 \\
\hline 3 & $\begin{array}{l}\text { Berat volume } \\
\text { agregat }\end{array}$ & $\begin{array}{l}\text { Berat } \\
\text { volume } \\
\text { kondisi } \\
\text { padat }\end{array}$ & $\begin{array}{c}1.500- \\
1.800 \\
\left(\mathrm{Gr} / \mathrm{cm}^{3}\right)\end{array}$ & 1.557 \\
\hline 4 & Analisa & $\begin{array}{l}\text { Nilai } \\
\text { modulus }\end{array}$ & $1,5-3,8$ & 2,92 \\
\hline
\end{tabular}
(pasir) yang dilakukan sebelum pembuatan benda uji dapat di lihat pada tabel 4.1.

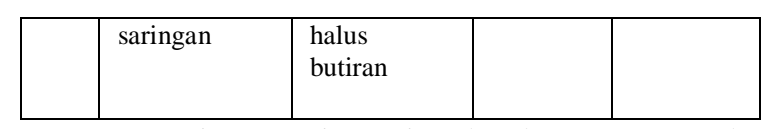

Pasir sungai musi Palembang termasuk dalam agregat normal karena masuk dalam spesifikasi berat jenisnya $2,5-2,7 \mathrm{gr} / \mathrm{cm}^{3}$. Begitu juga modulus kehalusan masuk spesifikasi yang diijinkan $1,5-3,8$

\section{B. Rancang Campuran Mortar}

Komposisi campuran mortar untuk 3 benda uji dibuat dengan standar ASTM C10993 yang dapat dilihat pada tabel 4.2. perbandingan bahan-bahan kering yang digunakan adalah 1 bagian berat semen 2,75 bagian berat pasir dan faktor air semen adalah 0,484 untuk semua jenis semen portland. Komposisi campuran Mortar Standar (MS) dan Mortar yang dicampur dengan Limbah abu tempurung kelapa şyij (MA) dapat di lihat pada tabel 4.2.

\begin{tabular}{|l|c|c|c|c|}
\hline \multicolumn{1}{|c|}{ Uraian } & MS\% & $\begin{array}{c}\text { MA- } \\
5 \%\end{array}$ & $\begin{array}{c}\text { MA- } \\
10 \%\end{array}$ & $\begin{array}{c}\text { MA- } \\
15 \%\end{array}$ \\
\hline $\begin{array}{l}\text { Limbah Abu } \\
\text { tempurung kelapa } \\
\text { sawit (gram) }\end{array}$ & 0 & 12,5 & 25 & 37,5 \\
\hline Semen (gram) & 250 & 250 & 250 & 250 \\
\hline Pasir (gram) & 687,5 & 687,5 & 687,5 & 687,5 \\
\hline Air (ml) & 121 & 121 & 121 & 121 \\
\hline
\end{tabular}

Keterangan :

MS $=$ Mortar Standar

MA-5\% = Mortar yang dicampur abu tempurung kelapa sawit 5\% terhadap berat semen

MA-10\% = Mortar yang dicampur abu tempurung kelapa sawit $10 \%$ terhadap berat semen

MA-15\% = Mortar yang dicampur abu tempurung kelapa sawit $15 \%$ terhadap berat semen

\section{Pengujian Kuat Tekan Mortar}

Pengujian kuat tekan mortar dilakukan dengan menggunakan alat Mesin Compressor (Compressor Mechine). Kuat tekan mortar dapat diperoleh dengan menggunakan rumus :

$f_{c}^{\prime}=\frac{F}{A}$

Dengan :

$$
\begin{aligned}
& \mathrm{f}_{\mathrm{c}}{ }^{\prime}=\text { Kuat tekan }\left(\mathrm{kg} / \mathrm{cm}^{2}\right) \\
& \mathrm{F}=\text { Gaya beban maksimum }(\mathrm{kg}) \\
& A=\text { Luas bidang permukaan }\left(\mathrm{cm}^{2}\right)
\end{aligned}
$$




\section{Hasil Pengujian Kuat Tekan Mortar}

Data hasil penelitian pengujian kekuatan tekan mortar standar dan mortar yang ditambah dengan abu cangkang kelapa sawit, tertera pada tabel 4.3. berikut :

\begin{tabular}{|c|c|c|c|c|}
\hline $\begin{array}{c}\text { Komposisi } \\
\text { Campuran }\end{array}$ & \multicolumn{3}{|c|}{ Kuat tekan rata-rata mortar } \\
\cline { 2 - 5 } (MS) & 7 hari & 14 hari & 21 hari & 28 hari \\
\hline Mortar Standar & 28,27 & 32,00 & 33,60 & 47,33 \\
\hline $\begin{array}{c}\text { Mortar Standar + } \\
5 \% \text { abu cangkang } \\
\text { kelapa sawit } \\
\text { (MS-5\%) }\end{array}$ & 26,80 & 30,40 & 32,13 & 43,87 \\
\hline $\begin{array}{c}\text { Mortar Standar + } \\
10 \% \text { abu } \\
\text { cangkang kelapa } \\
\text { sawit (MS-10\%) }\end{array}$ & 25,33 & 28,67 & 30,13 & 38,13 \\
\hline $\begin{array}{c}\text { Mortar Standar + } \\
\text { 15\% abu } \\
\text { cangkang kelapa } \\
\text { sawit (MS-15\%) }\end{array}$ & 24,40 & 27,60 & 28,87 & 36,00 \\
\hline
\end{tabular}

Grafik 4.1. Rekapitulasi Hasil Pengujian Kuat Tekan Mortar

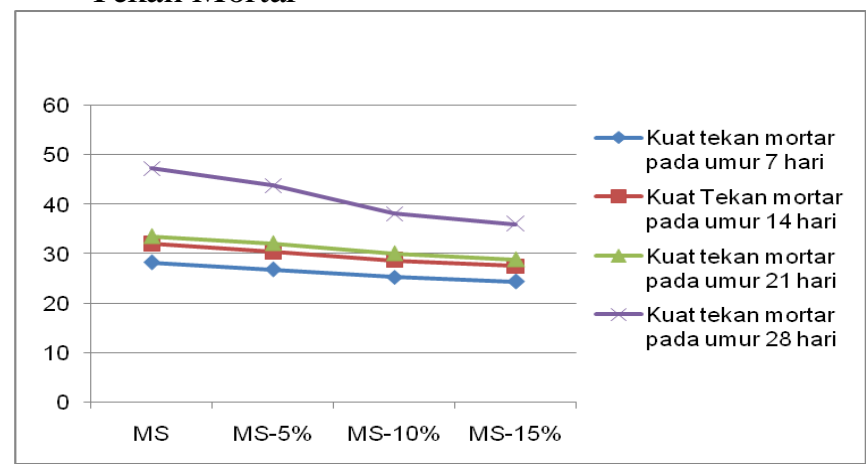

Dari grafik 4.1. dapat dilihat bahwa kuat tekanan rata-rata mortar pada umur 28 hari tidak menggunakan limbah abu tempurung kelapa sawit $(0 \%)$ sebagai tambahan pada campuran mortar atau mortar standar adalah sebesar $47,33 \mathrm{~kg} / \mathrm{cm}^{2}$, sedangkan untuk kuat tekan rata-rata mortar pada umur 28 hari menggunakan limbah abu tempurung kelapa sawit sebagai tambahan pada campuran mortar sebesar 5\%, 10\%, 15\% dari berat semen, berturut-turut adalah $43,87 \mathrm{~kg} / \mathrm{cm}^{2}, 38,13$ $\mathrm{kg} / \mathrm{cm}^{2}$, dan $36,00 \mathrm{~kg} / \mathrm{cm}^{2}$.

\section{PENUTUP}

\section{A. Kesimpulan}

Dari hasil penelitian dan pengujian kuat tekan mortar dengan menggunakan limbah abu tempurung kelapa sawit sebagai bahan tambahan pada campuran mortar sebesar $0 \%, 5 \%, 10 \%, 15 \%$ dari berat semen dapat disimpulkan bahwa :

1. Nilai kuat tekan mortar dengan komposisi campuran Mortar Standar (MS) kuat tekan rata-rata mortar pada umur 28 hari yaitu $47,33 \mathrm{~kg} / \mathrm{cm}^{2}$

2. Nilai kuat tekan mortar dengan komposisi campuran Mortar Standar $+5 \%$ abu cangkang kelapa sawit (MS-5\%), kuat tekan rata-rata mortar pada umur 28 hari yaitu $43,87 \mathrm{~kg} / \mathrm{cm}^{2}$

3. Nilai kuat tekan mortar dengan komposisi campuran Mortar Standar $+10 \%$ abu cangkang kelapa sawit (MS-10\%), kuat tekan rata-rata mortar pada umur 28 hari yaitu $38,13 \mathrm{~kg} / \mathrm{cm}^{2}$

4. Nilai kuat tekan mortar dengan komposisi campuran Mortar Standar $+15 \%$ abu cangkang kelapa sawit (MS-15\%), kuat tekan rata-rata mortar pada umur 28 hari yaitu $36,00 \mathrm{~kg} / \mathrm{cm}^{2}$

Dengan demikian penggunaan limbah abu tempurung kelapa sawit dengan komposisi penambahan 5\% dari berat semen, kuat tekan rata-rata mortar umur 28 hari yaitu 43,87 $\mathrm{kg} / \mathrm{cm}^{2}$ merupakan kadar campuran optimum pada campuran ini, tapi nilainya tidak lebih dari kuat tekan mortar normal.

\section{B. Saran}

Diharapkan dapat dilakukan penelitian lanjutan dengan campuran limbah abu tempurung kelapa sawit dengan variasi lama rendaman (perawatan). 


\section{DAFTAR PUSTAKA}

[1] Tjokrodimulyo, K., 1992, "Teknologi Beton", Buku Ajar Pada Jurusan Teknik Sipil, Fakultas Teknik Sipil, Universitas Gajah Mada. Yogyakarta.

[2] Tjokrodimuljo, K., 2003, Teknologi Bahan Konstruksi, Buku Ajar. Jurusan Teknik Sipil, Universitas Atma Jaya. Yogyakarta.

[3] Persyaratan Umum Bahan Bangunan Di Indonesia (PUBI-1982) Direktorat Penyelidikan Masalah Bangunan.

[4] SNI 03-1970-2008 Cara Uji Berat Jenis dan penyerapan air agregat halus, Badan Standarisasi Nasional

[5] SNI 03 - 2834-2000 "Tata Cara Pembuatan Campuran Beton Normal" Badan Standarisasi nasional (BSN) ICS 91.100.30

[6] SNI 03-1974-1990 Metode pengujian kuat tekan beton, badan standarisasi nasional (BSC) ICS 91.100.30

[7] Mulyono, T. 2003. Teknologi Beton. Andi: Yogyakarta.

[8] Bayu Krisfinanto : Metode Perawatan Beton (Curing), bayugembell.blogspot.co.id 2011.

[9] Tjokrodimulyo, K. 1996. Teknologi Beton. Nafiri: Yogyakarta.

[10] SNI 03-1968-1990 Metode Pengujian Analisa Saringan Agregat halus dan Kasar, Badan Standarisasi Nasional

[11] SNI 03-1972-1990 Metode Pengujian Slump Beton, Badan Standarisasi Nasional

[12] SNI 03-6820-2002 (2002:171),

[13] Persyaratan batu pecah yang digunakan dalam campuran beton (1982) Departemen Pekerjaan Umum.

[14] Tjokrodimulyo, K. 1996. Teknologi Beton. Nafiri: Yogyakarta.

[15] Dept. Pekerjaan Umum, Tata Cara Perhitungan Harga Satuan Pekerjaan Beton (SNI DT-91-0008-2007).

[16] Dipohusodo, I. 1999. Struktur Beton Bertulang Berdasarkan SK SNI-T-151991-03 Departemen Pekerjaan Umum RI. PT Gramedia Pustaka Utama : Jakarta.

[17] SK SNI-S-04-1989-F, "SPESIFIKASI BAHAN BANGUNAN BAGIAN A)

[18] Duff Abrams (1919) dalam Samekto dan Rahmadiyanto (2001: 43) 